\title{
Efficacy and safety of immune checkpoint inhibitors in colorectal cancer: a systematic review and meta-analysis
}

\author{
Tianni Zeng ${ }^{1,3} \cdot$ Xiaojie Fang $^{2} \cdot$ Jinhua Lu ${ }^{1} \cdot$ Yazhen Zhong ${ }^{1} \cdot$ Xianlei Lin ${ }^{1} \cdot$ Zechen Lin ${ }^{1} \cdot$ Nan Wang $^{4} \cdot$ Jing Jiang $^{3}$. \\ Shengyou Lin ${ }^{1}(1)$
}

Accepted: 9 September 2021 / Published online: 29 October 2021

(c) The Author(s) 2021

\begin{abstract}
Background and objective Immune checkpoint inhibitor (ICI) therapies have shown promising prospects in colorectal cancer (CRC) immunotherapy; many clinical trials have been carried out. In this study, we sought to evaluate the efficacy and safety of ICI therapies in CRC by presenting a meta-analysis of relevant studies.

Methods Databases including PubMed, Embase, Cochrane Library, and Web of Science were systematically searched for studies concerning the efficacy and safety of ICI in colorectal cancer. The reported odds ratio $(O R)$ or weighted mean difference $(W M D)$ with $95 \%$ confidence intervals $(C I s)$ of overall survival $(O S)$, progression-free survival $(P F S)$, objective response rate $(O R R)$, disease control rate $(D C R)$, treatment-related adverse events (TRAEs), and TRAEs $\geq 3$ in the included studies were analyzed by fixed effects/random effects models.

Results Three studies involving 667 patients with colorectal cancer were included in our meta-analysis. No significant difference between the immune checkpoint inhibitor therapies and conventional therapies in $O S$ (WMD $=0.73,95 \% C I-3.09$, $4.54 ; p=0.71)$, in $\operatorname{ORR}(O R=1.54,95 \% C I 0.98,2.40 ; p=0.06)$, and in DCR $(O R=0.97,95 \% C I 0.36,2.61 ; p=0.95)$. The median PFS of the ICI therapy group was shorter than that of the conventional therapy group (WMD $=-0.10,95 \%$ $C I-0.18,-0.02 ; p=0.02$ ). At the same time, we also could not find a significant difference between the immune checkpoint inhibitor therapies and conventional therapies in TRAEs $(O R=1.56,95 \% C I 0.11,22.09 ; p=0.74)$ and in $T R A E \mathrm{~s} \geq 3$ $(O R=0.94,95 \%$ CI 0.16, 5.65; $p=0.95)$.

Conclusion Immune checkpoint inhibitor therapies could not improve all survival endpoints to advanced or metastatic colorectal cancer patients. Whether immune checkpoint inhibitors should be the first choice of therapies for colorectal cancer patients with undetermined microsatellite status or not able to determine microsatellite status needs more related studies to prove.
\end{abstract}

Keywords Programmed death ligand 1 inhibitor $\cdot$ Programmed cell death protein 1 inhibitor · Immune checkpoint inhibitors $\cdot$ Colorectal cancer $\cdot$ Efficacy $\cdot$ Safety

Tianni Zheng and Xiaojie Fang contributed equally to this work

Shengyou Lin

linsy0628@126.com

1 Department of Oncology, Hangzhou TCM hospital Affiliated to Zhejiang Chinese Medical University, Hangzhou, China

2 Department of Anorectal Surgery, Hangzhou TCM hospital Affiliated to Zhejiang Chinese Medical University, Hangzhou, China
3 The Third Clinical Medical College, Zhejiang Chinese Medical University, Hangzhou, China

4 The First People's Hospital of Xiaoshan District, Hangzhou, China 


\section{Introduction}

Globally, colorectal cancer is the fourth most fatal cancer, with approximately 0.9 million annual mortalities. It is the second most common tumor among women and the third most common tumor among men [1]. Colorectal cancer accounts for about $10 \%$ of all annually diagnosed cancers and cancer-related mortalities [2]. Morbidity and mortality rates are highest in the developed countries. By the year 2035, annual global incidences of colorectal cancer are predicted to increase to 2,500,000 [3].

Since clinical symptoms of colorectal cancer occur late, most patients are diagnosed when the disease is in the advanced stages [1]. Depending on cancer characteristics, firstline therapy for advanced CRC is combination chemotherapy plus an anti-epidermal growth factor receptor (EGFR) antibody or anti-vascular endothelial growth factor (VEGF) [4, 5]; however, progression-free survival time for most patients is within 9-12 months [6-13]. Therefore, there is a need to develop effective therapeutic options with fewer side effects.

Immunotherapy has improved tumor treatment [14]. In this context, metastatic colorectal cancer represents an intriguing entity, with a minority (4-5\%) of tumors which harbor microsatellite instability (MSI) and/or mismatch repair deficiency
(dMMR) being highly sensitive to immune checkpoint inhibitors, while a vast majority of immunologically "cold" tumors are refractory to immunotherapeutic strategies [15]. It has been confirmed that immune checkpoint inhibitors play an important role in colorectal cancer patients that are mismatch repair deficient (dMMR) [16, 17]. Some humanized monoclonal antibodies, including ipilimumab, nivolumab, pembrolizumab, avelumab, atezolizumab, and durvalumab among others, have been developed. These drugs have been approved for use in malignant cancers such as melanoma, non-small cell lung cancer, urothelial carcinoma, Hodgkin's lymphoma, and head and neck squamous carcinoma among others [18]. The National Comprehensive Cancer Network guidelines recommend pembrolizumab or nivolumab as second-line therapeutic options especially for patients with dMMR/MSI-high mCRC [19]. However, questions remain concerning the role of immune checkpoint inhibitors (ICIs) for the treatment of microsatellite-stable (MSS) and mismatch repair-proficient (pMMR) CRC. It has not been established if the efficacy of immune checkpoint inhibitors is superior to that of other therapies for colorectal cancer, whether with pMMR or dMMR. Therefore, we performed a meta-analysis of various clinical trials involving colorectal cancer to evaluate the safety and efficacy of immune checkpoint inhibitors.

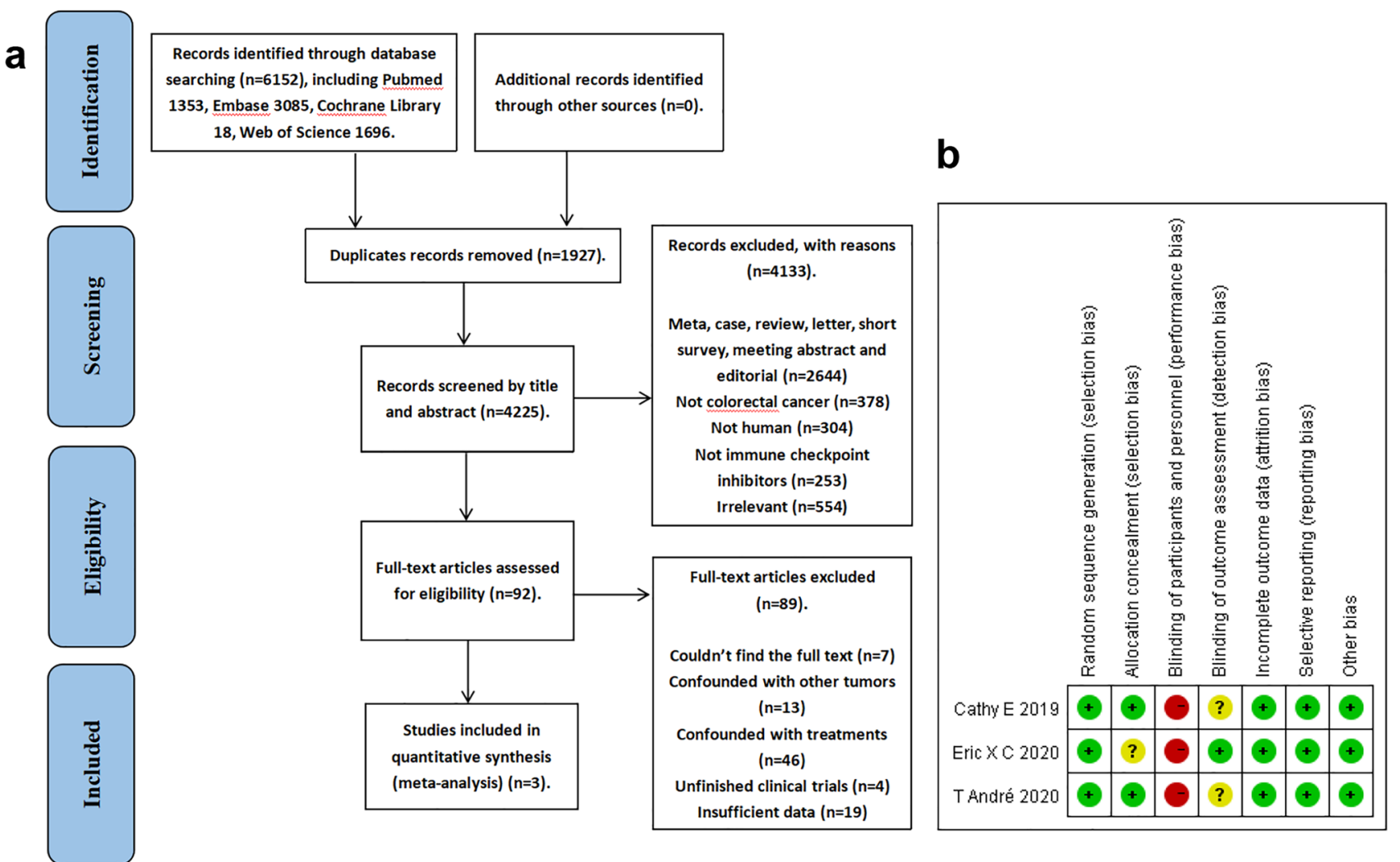

Fig.1 a Flowchart of the study selection process. b Risk of bias summary of randomized controlled trials. + low risk, ? unclear risk, - high risk 


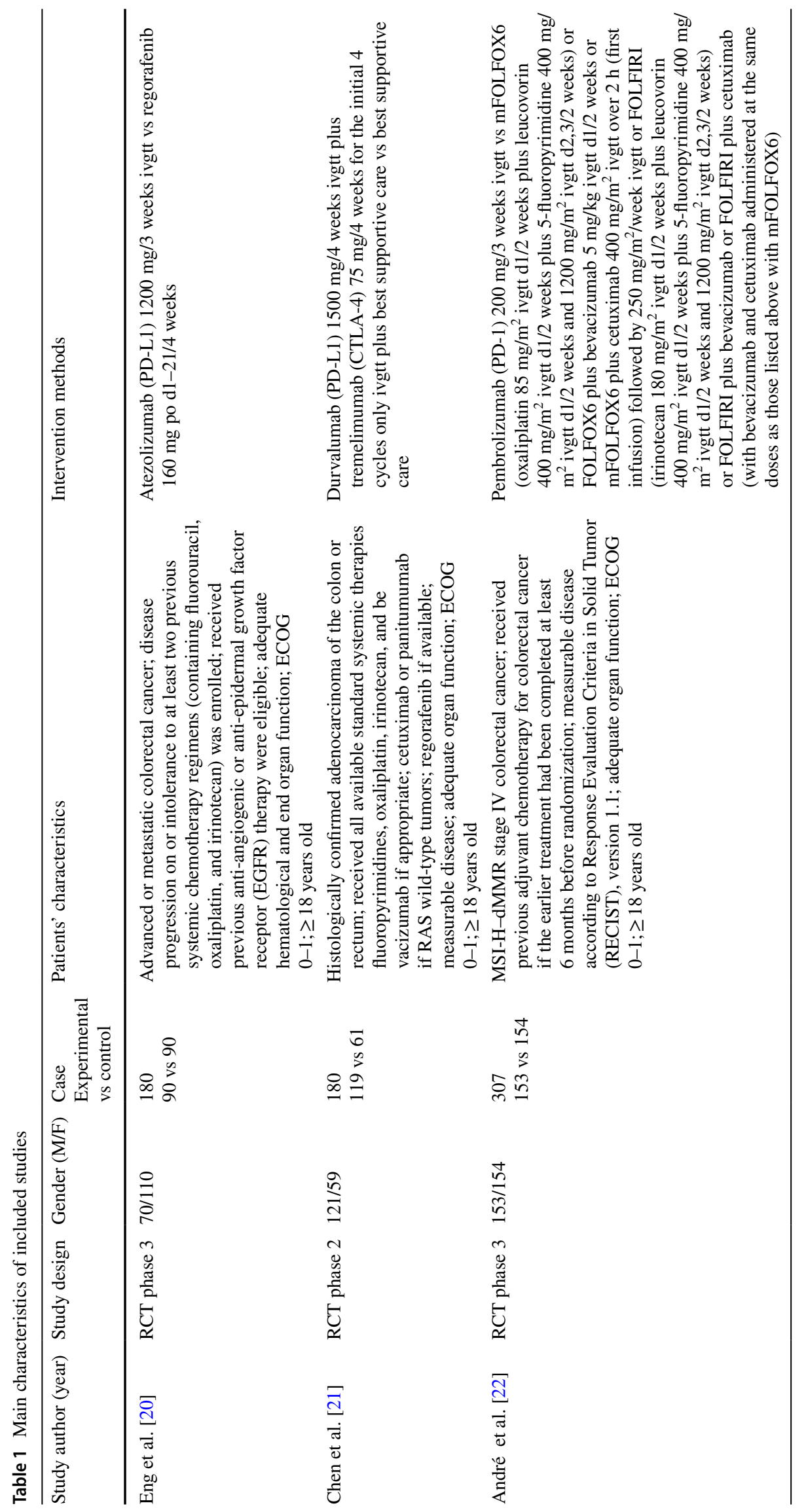




\section{Methods}

The systematic review protocol for this study was registered in PROSPERO (registration number CRD42021238819).

\section{Literature search strategies}

Electronic databases, including PubMed, Embase, Cochrane Library, and Web of Science, were searched. We searched the literature from inception to March 2021 without restriction of language. In our search strategy, the MeSH terms combined with related words and keywords were adjusted to comply with the relevant rules in each database. Search terms included "colorectal neoplasm," "colorectal tumor," "b7 h1 antigen," "cd274 antigen," "programmed cell death protein 1 inhibitor," "programmed death ligand 1 inhibitor," "immune checkpoint inhibitors," "nivolumab," "pembrolizumab," "atezolizumab," "durvalumab," "avelumab," and "ipilimumab." All entries that satisfied these criteria were manually retrieved.

\section{Inclusion and exclusion criteria}

The inclusion criteria for eligible studies were (i) confirmed diagnosis of colorectal cancer; (ii) data on overall survival $(O S)$ or progression-free survival $(P F S)$ were available for evaluating the efficacy of immune checkpoint inhibitors; (iii) security indicators, including treatment-related adverse events (TRAEs), grade $\geq 3$ TRAEs were directly provided or could be calculated; and (iv) RCTs, irrespective of the blinding method or lack of, were also included. Animal studies, reviews, editorials, comments, meetings, or case reports were excluded. Studies with duplicate publications, unbalanced matching procedures, or incomplete data were also excluded.

\section{Data extraction}

Two reviewers (Fang $x j$ and Lin $x l$ ) independently extracted the data according to the prescribed selection criteria. Differences in opinion were resolved by discussion between the authors or by obtaining an opinion from a third evaluator. The following data were extracted: the name of the first author, year of publication, number of patients, study design, age, gender, tumor types, previous treatment, organ status, Eastern Cooperative Oncology Group (ECOG) performance status, intervention methods, and statistical data including OS, PFS, ORR, DCR, TRAEs, and grade $\geq 3$ TRAEs. Where necessary, corresponding authors were contacted to obtain supplementary information.
Fig. 2 Forest plots of different subgroups. a $O S$ time. b Median PFS time. c ORR. d DCR. e TRAEs. f TRAEs $\geq 3$. CI confidence interval, $O S$ overall survival, $P F S$ progression-free survival, $O R R$ objective response rate, $D C R$ disease control rate, TRAEs treatment-related adverse events, $O R$ odd risk, $W M D$ weighted mean difference

\section{Quality assessment}

Cochrane Collaboration's tool for assessing risk of bias was used for assessing the quality of each included study (Fig. 1b). For evaluating selection bias, performance bias, detection bias, attrition bias, reporting bias, and other bias, there were seven items provided by the tool. They contained random sequence generation, allocation concealment, blinding of participants and personnel, blinding of outcome assessment, incomplete outcome data, selective reporting, and other bias. Each item was answered with one of the three replies: low risk, unclear risk, and high risk to assess the bias.

\section{Statistical analysis}

Data were extracted from the primary studies and analyzed using Review Manager (version 5.3, Cochrane Collaboration, Oxford, UK). We expressed results for dichotomous outcomes as odd risk with $95 \%$ confidence intervals (CIs) and continuous outcomes as weighted mean difference. In the absence of statistical heterogeneity, a fixed effects model was used to pool data. In cases of statistical heterogeneity $\left(p<0.05, I^{2} \geq 50 \%\right)$, a random effects model was used.

\section{Results}

\section{Search results}

From the systematic database search, we retrieved 6152 articles. Based on the inclusion criteria, at total of 6149 articles were excluded, with 3 [20-22] articles being eligible for the meta-analysis (Fig. 1a). From the included studies, a total of 667 patients were enrolled. Characteristics of all included studies are shown in Table 1.

\section{Meta-analysis}

\section{Overall survival (OS)}

Data on median overall survival outcomes for the 360 CRC patients were obtained. There was no significant difference between the outcomes of immune checkpoint inhibitor therapy and conventional therapy $(W M D=0.73$, 95\% $C I-3.09,4.54 ; p=0.71)$. Significant heterogeneity was observed in these studies ( $p=0.03 ; I^{2}=80 \%$; Fig. 2a). 
a

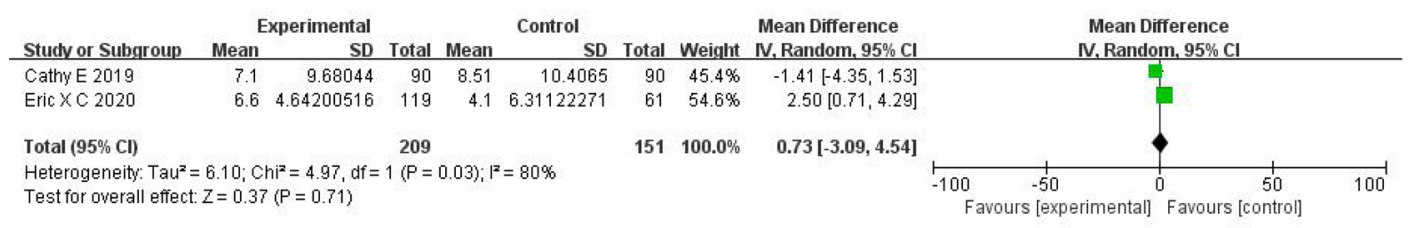

\section{b}

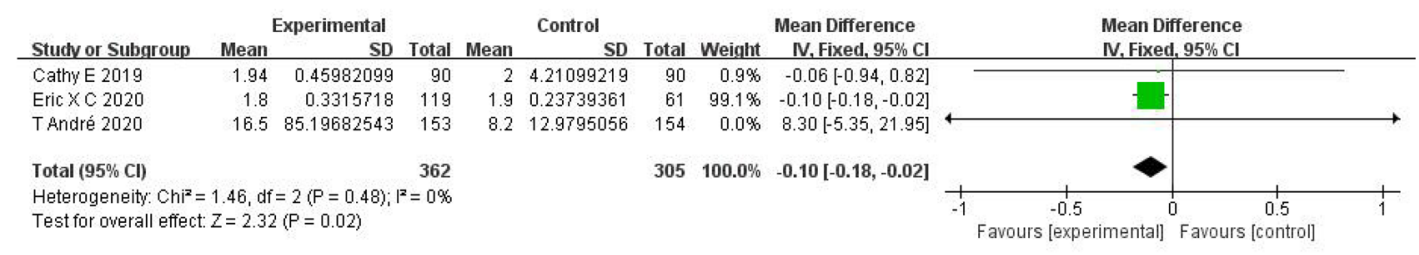

C

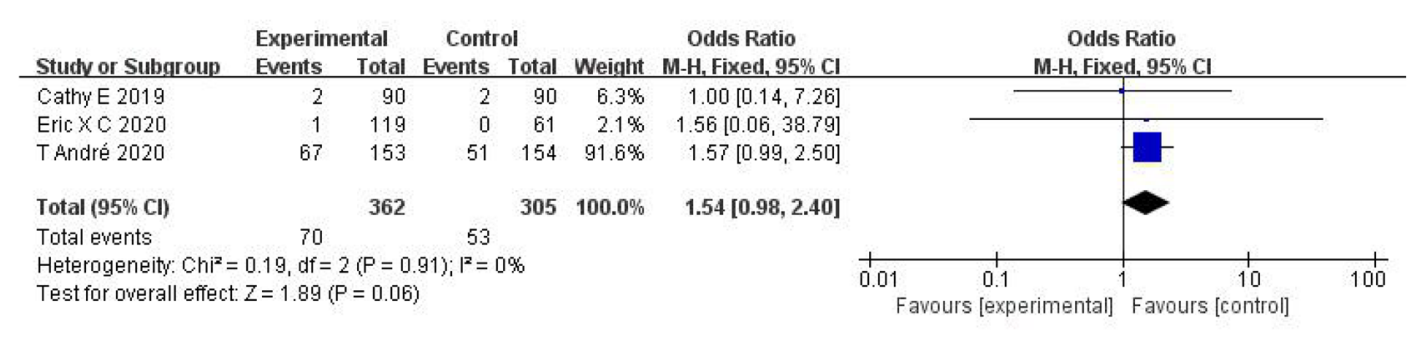

\section{d}

Experimental Control

Odds Ratio

Odds Ratio

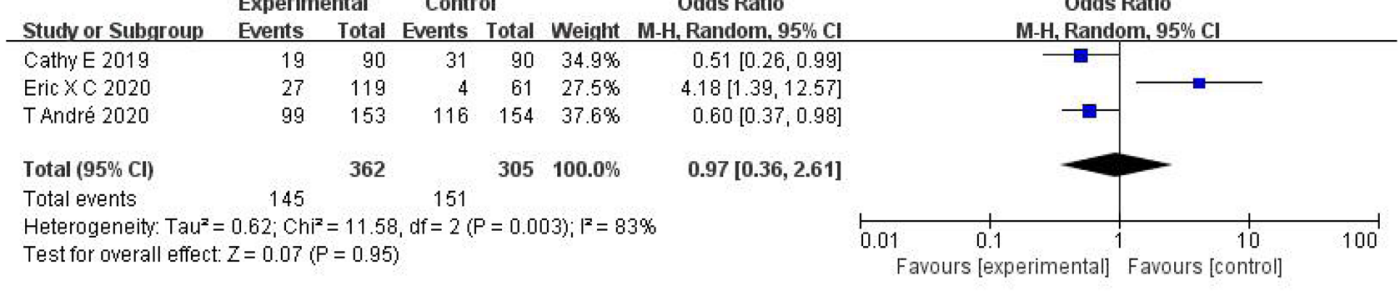

\section{e}

Experimental Control Odds Ratio Studv or Subgroup Events Total Events Total Weight M-H, Random. $95 \% \mathrm{CI}$ $\begin{array}{lrrrrrr}\text { Cathy E 2019 } & 83 & 90 & 76 & 80 & 38.7 \% & 0.62[0.18,2.22] \\ \text { Eric XC 2020 } & 118 & 118 & 52 & 61 & 28.4 \% & 42.89[2.45,750.59] \\ \text { TAndré 2020 } & 149 & 153 & 142 & 143 & 32.8 \% & 0.26[0.03,2.38]\end{array}$

361

$361 \quad 284 \quad 100.0 \%$ $0.26[0.03,2.38]$

Total $(95 \% \mathrm{Cl})$ Total events $\quad 350 \quad 270$ Heterogeneity: $\operatorname{Tau}^{2}=4.30 ; \mathrm{Chi}^{2}=9.97, \mathrm{df}=2(\mathrm{P}=0.007) ; \mathrm{F}^{2}=80 \%$ Test for overall effect: $Z=0.33(\mathrm{P}=0.74)$

$1.56[0.11,22.09]$

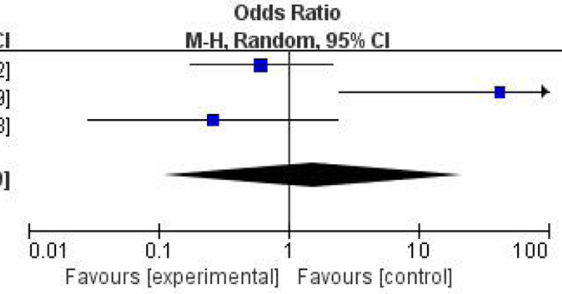

\section{f}

Experimental Control Odds Ratio

\begin{tabular}{|c|c|c|c|c|c|c|}
\hline Studv or Subqroup & Events & Total & Events & Total & Weight & M-H, Random, $95 \% \mathrm{Cl}$ \\
\hline Cathy E 2019 & 28 & 90 & 46 & 80 & $33.3 \%$ & $0.33[0.18,0.63]$ \\
\hline Eric $\times C 2020$ & 75 & 118 & 12 & 61 & $32.8 \%$ & $7.12[3.42,14.84]$ \\
\hline T André 2020 & 86 & 153 & 111 & 143 & $33.8 \%$ & $0.37[0.22,0.61]$ \\
\hline Total $(95 \% \mathrm{Cl})$ & & 361 & & 284 & $100.0 \%$ & $0.94[0.16,5.6$ \\
\hline Total events & 189 & & 169 & & & \\
\hline $\begin{array}{l}\text { Heterogeneity: Tau } \\
\text { Test for overall effer }\end{array}$ & $\begin{array}{l}2.39 ; \mathrm{ch} \\
Z=0.06\end{array}$ & $\begin{array}{l}=50.28 \\
=0.95\end{array}$ & $\mathrm{df}=2(\mathrm{~F}$ & $0<0.0$ & $0001) ;\left.\right|^{2}=$ & $96 \%$ \\
\hline
\end{tabular}

Test for overall effect: $Z=0.06(P=0.95)$

Odds Ratio 


\section{Progression-free survival (PFS)}

For the 667 CRC patients, the median progression-free survival time of the immune checkpoint inhibitor therapy group was significantly shorter than that of the conventional therapy group $(W M D=-0.10,95 \% C I-0.18,-0.02 ; p=0.02)$. Significant heterogeneity was not observed in these studies $\left(p=0.48 ; I^{2}=0 \%\right.$; Fig. 2b).

\section{Objective response rate (ORR)}

There was no significant difference in $O R R$ between the two groups $(O R=1.54,95 \% C I 0.98,2.40 ; p=0.06)$. Significant heterogeneity was not observed in these studies $(p=0.91$; $I^{2}=0 \%$; Fig. 2c).

\section{Disease control rate (DCR)}

There was no significant difference in $D C R$ between the immune checkpoint inhibitor therapy group and the conventional therapy group $(O R=0.97,95 \% C I \quad 0.36,2.61$; $p=0.95)$. Significant heterogeneity was found in these studies $\left(p=0.003 ; I^{2}=83 \%\right.$; Fig. $\left.2 \mathrm{~d}\right)$.

\section{Treatment-related adverse events (TRAEs)}

Incidences of TRAEs in the immune checkpoint inhibitor therapy group and conventional therapy group were $97.0 \%$ and $95.1 \%$, respectively, a difference that was not significant $(O R=1.56,95 \%$ CI 0.11, 22.09; $p=0.74)$. Significant heterogeneity was observed in these studies $\left(p=0.007 ; I^{2}=80 \%\right.$; Fig. 2e). Incidences of TRAEs $\geq 3$ in the immune checkpoint inhibitor therapy and conventional therapy groups were $52.4 \%$ and $59.5 \%$, respectively, a difference that was not significant $(O R=0.94,95 \% C I 0.16,5.65 ; p=0.95)$. Significant heterogeneity was observed in these studies $(p<0.00001$; $I^{2}=96 \%$; Fig. 2f).

\section{Discussion}

This is the first meta-analysis to evaluate the efficacy and safety of immune checkpoint inhibitors, including PD-1, PD-L1, and CTLA-4 antibodies, as therapeutic options for colorectal cancer. We found that differences in overall survival outcomes were not significant between the immune checkpoint inhibitor group and the group with other therapeutic options (including chemotherapy and best supportive care). Treatment with immune checkpoint inhibitors was associated with poor progression-free survival. In objective response and disease control rates, there was no significant difference between the two groups. More than half of patients in the immune checkpoint inhibitor therapy group exhibited $\geq 3 T R A E$ s, with the incidence in the immune checkpoint inhibitor therapy group being lower than that of the conventional therapy group. However, ORs for TRAEs and $\geq 3 T R A E$ s were not significantly different between the immune checkpoint inhibitor therapy and the conventional therapy groups. ICI therapy did not exhibit any particular advantage over conventional therapy in advanced CRC patients. Moreover, incidences of adverse events in the ICI therapy group were not significantly lower than those of the conventional therapy group in advanced CRC patients.

It has been shown that compared to chemotherapy, immune checkpoint inhibitors exhibit unique response and survival outcomes for patients with advanced mismatch repair-deficient/microsatellite-unstable (dMMR/MSI) colorectal cancer, but have shown disappointing results in mismatch repair-proficient/microsatellite-stable (pMMR/ MSS) colorectal cancer patients [15, 19, 23]. Negative results could be attributed to the lack of comparisons of the efficacy and safety of immune checkpoint inhibitors in dMMR/MSI colorectal cancer and pMMR/MSS colorectal cancer. Currently, the number of RCTs evaluating the efficacy and safety of immune checkpoint inhibitors in dMMR/MSI colorectal cancer and pMMR/MSS colorectal cancer is very small. More RCTs are needed to confirm our results.

This study is associated with some limitations. First, we only used three RCTs. The sample size was relatively small. Second, we generally analyzed dMMR/MSI and pMMR/ MSS colorectal cancer patients, and we did not perform subgroup analysis based on colorectal cancer microsatellite status. Studies should aim at evaluating whether the efficacy and safety of immune checkpoint inhibitors change according to the microsatellite status of CRC. Finally, despite applications of the random effects model, there was substantive heterogeneity in some of the results. We could not use subgroup and sensitivity analyses because the number of the included studies was relatively small.

\section{Conclusion}

Immune checkpoint inhibitor therapies have no particular advantage over non-immune checkpoint inhibitor therapies. Moreover, incidences of adverse events due to immune checkpoint inhibitor therapy are not significantly lower than those of non-immune checkpoint inhibitor therapy. Therefore, under the existing evidence, immune checkpoint inhibitors should not be first choice therapies for colorectal cancer patients with undetermined microsatellite status.

Acknowledgements We would like to thank Home for Researchers editorial team (www.home-for-researchers.com) for English language editing of the manuscript. 
Author contribution Tianni Zeng: Conceptualization, data curation, formal analysis, investigation, writing - original draft, writing review and editing. Xiaojie Fang: Data curation, formal analysis, writing - original draft, writing - review and editing. Jinhua Lu: Formal analysis, writing — original draft, writing — review and editing. Yazhen Zhong: Formal analysis, writing — original draft, writing - review and editing. Xianlei Lin: Data curation, writing - original draft, writing - review and editing. Zechen Lin: Investigation, writing — original draft, writing — review and editing. Nan Wang: Investigation, writing — original draft, writing — review and editing. Jing Jiang: Investigation, writing — original draft, writing — review and editing. Shengyou Lin: Data curation, formal analysis, funding acquisition, supervision, writing — original draft, writing - review and editing.

Funding This work was financially supported through grants from the science and technology planning projects of Zhejiang Province (2018C03025), the Program of Zhejiang Provincial TCM Sci-tech Plan (2020ZQ041), and Zhejiang Lin Shengyou famous traditional Chinese medicine expert inheritance studio project (GZS202002).

\section{Declarations}

Conflict of interest The authors declare no competing interests.

Open Access This article is licensed under a Creative Commons Attribution 4.0 International License, which permits use, sharing, adaptation, distribution and reproduction in any medium or format, as long as you give appropriate credit to the original author(s) and the source, provide a link to the Creative Commons licence, and indicate if changes were made. The images or other third party material in this article are included in the article's Creative Commons licence, unless indicated otherwise in a credit line to the material. If material is not included in the article's Creative Commons licence and your intended use is not permitted by statutory regulation or exceeds the permitted use, you will need to obtain permission directly from the copyright holder. To view a copy of this licence, visit http://creativecommons.org/licenses/by/4.0/.

\section{References}

1. Dekker E, Tanis PJ, Vleugels JLA, Kasi PM, Wallace MB (2019) Colorectal cancer. Lancet 394(10207):1467-1480. https://doi.org/ 10.1016/S0140-6736(19)32319-0 (PMID: 31631858)

2. Bray F, Ferlay J, Soerjomataram I, Siegel RL, Torre LA, Jemal A (2018) Global cancer statistics 2018: GLOBOCAN estimates of incidence and mortality worldwide for 36 cancers in 185 countries. CA Cancer J Clin 68(6):394-424. https://doi.org/10.3322/ caac.21492. Epub 2018 Sep 12. Erratum in: CA Cancer J Clin 70(4):313. PMID: 30207593

3. Arnold M, Sierra MS, Laversanne M, Soerjomataram I, Jemal A, Bray F (2017) Global patterns and trends in colorectal cancer incidence and mortality. Gut 66(4):683-691. https://doi.org/10. 1136/gutjnl-2015-310912 (Epub 2016 Jan 27 PMID: 26818619)

4. Benson AB, Venook AP, Al-Hawary MM, Arain MA, Chen YJ, Ciombor KK, Cohen S, Cooper HS, Deming D, Farkas L, GarridoLaguna I, Grem JL, Gunn A, Hecht JR, Hoffe S, Hubbard J, Hunt S, Johung KL, Kirilcuk N, Krishnamurthi S, Messersmith WA, Meyerhardt J, Miller ED, Mulcahy MF, Nurkin S, Overman MJ, Parikh A, Patel H, Pedersen K, Saltz L, Schneider C, Shibata D, Skibber JM, Sofocleous CT, Stoffel EM, Stotsky-Himelfarb E, Willett CG, Gregory KM, Gurski LA (2021) Colon Cancer, Version 2. 2021, NCCN Clinical Practice Guidelines in Oncology. J
Natl Compr Canc Netw 2;19(3):329-359. https://doi.org/10.6004/ jnccn.2021.0012. PMID: 33724754

5. Benson AB, Venook AP, Al-Hawary MM, Arain MA, Chen YJ, Ciombor KK, Cohen S, Cooper HS, Deming D, GarridoLaguna I, Grem JL, Gunn A, Hoffe S, Hubbard J, Hunt S, Kirilcuk N, Krishnamurthi S, Messersmith WA, Meyerhardt J, Miller ED, Mulcahy MF, Nurkin S, Overman MJ, Parikh A, Patel H, Pedersen K, Saltz L, Schneider C, Shibata D, Skibber JM, Sofocleous CT, Stoffel EM, Stotsky-Himelfarb E, Willett CG, Johnson-Chilla A, Gurski LA (2020) NCCN Guidelines Insights: Rectal Cancer, Version 6. 2020. J Natl Compr Canc Netw 18(7):806-815. https://doi.org/10.6004/jnccn.2020.0032. PMID: 32634771

6. Saltz LB, Clarke S, Díaz-Rubio E, Scheithauer W, Figer A, Wong R, Koski S, Lichinitser M, Yang TS, Rivera F, Couture F, Sirzén F, Cassidy J (2008) Bevacizumab in combination with oxaliplatinbased chemotherapy as first-line therapy in metastatic colorectal cancer: a randomized phase III study. J Clin Oncol 26(12):20132019. https://doi.org/10.1200/JCO.2007.14.9930.Erratum.In: JClin Oncol.2008J un;26(18):3110.Erratumin:JClin Oncol. 2009Feb1;27(4):653 (PMID: 18421054)

7. Heinemann V, von Weikersthal LF, Decker T, Kiani A, VehlingKaiser U, Al-Batran SE, Heintges T, Lerchenmüller C, Kahl C, Seipelt G, Kullmann F, Stauch M, Scheithauer W, Hielscher J, Scholz M, Müller S, Link H, Niederle N, Rost A, Höffkes HG, Moehler M, Lindig RU, Modest DP, Rossius L, Kirchner T, Jung A, Stintzing S (2014) FOLFIRI plus cetuximab versus FOLFIRI plus bevacizumab as first-line treatment for patients with metastatic colorectal cancer (FIRE-3): a randomised, open-label, phase 3 trial. Lancet Oncol 15(10):1065-1075. https://doi.org/10.1016/ S1470-2045(14)70330-4 (Epub 2014 Jul 31 PMID: 25088940)

8. Douillard JY, Siena S, Cassidy J, Tabernero J, Burkes R, Barugel M, Humblet Y, Bodoky G, Cunningham D, Jassem J, Rivera F, Kocákova I, Ruff P, Błasińska-Morawiec M, Šmakal M, Canon JL, Rother M, Oliner KS, Wolf M, Gansert J (2010) Randomized, phase III trial of panitumumab with infusional fluorouracil, leucovorin, and oxaliplatin (FOLFOX4) versus FOLFOX4 alone as first-line treatment in patients with previously untreated metastatic colorectal cancer: the PRIME study. J Clin Oncol 28(31):46974705. https://doi.org/10.1200/JCO.2009.27.4860 (Epub 2010 Oct 4 PMID: 20921465)

9. Loupakis F, Cremolini C, Masi G, Lonardi S, Zagonel V, Salvatore L, Cortesi E, Tomasello G, Ronzoni M, Spadi R, Zaniboni A, Tonini G, Buonadonna A, Amoroso D, Chiara S, Carlomagno C, Boni C, Allegrini G, Boni L, Falcone A (2014) Initial therapy with FOLFOXIRI and bevacizumab for metastatic colorectal cancer. N Engl J Med 371(17):1609-1618. https://doi.org/10.1056/ NEJMoa1403108 (PMID: 25337750)

10. Douillard JY, Siena S, Cassidy J, Tabernero J, Burkes R, Barugel M, Humblet Y, Bodoky G, Cunningham D, Jassem J, Rivera F, Kocákova I, Ruff P, Błasińska-Morawiec M, Šmakal M, Canon JL, Rother M, Oliner KS, Tian Y, Xu F, Sidhu R (2014) Final results from PRIME: randomized phase III study of panitumumab with FOLFOX4 for first-line treatment of metastatic colorectal cancer. Ann Oncol 25(7):1346-1355. https://doi.org/10.1093/annonc/ mdu141 (Epub 2014 Apr 8 PMID: 24718886)

11. Falcone A, Ricci S, Brunetti I, Pfanner E, Allegrini G, Barbara C, Crinò L, Benedetti G, Evangelista W, Fanchini L, Cortesi E, Picone V, Vitello S, Chiara S, Granetto C, Porcile G, Fioretto L, Orlandini C, Andreuccetti M, Masi G (2007) Gruppo Oncologico Nord Ovest. Phase III trial of infusional fluorouracil, leucovorin, oxaliplatin, and irinotecan (FOLFOXIRI) compared with infusional fluorouracil, leucovorin, and irinotecan (FOLFIRI) as first-line treatment for metastatic colorectal cancer: the Gruppo Oncologico Nord Ovest. J Clin Oncol 25(13):1670-6. https://doi. org/10.1200/JCO.2006.09.0928. PMID: 17470860 
12. Van Cutsem E, Köhne CH, Láng I, Folprecht G, Nowacki MP, Cascinu S, Shchepotin I, Maurel J, Cunningham D, Tejpar S, Schlichting M, Zubel A, Celik I, Rougier P, Ciardiello F (2011) Cetuximab plus irinotecan, fluorouracil, and leucovorin as firstline treatment for metastatic colorectal cancer: updated analysis of overall survival according to tumor KRAS and BRAF mutation status. J Clin Oncol 29(15):2011-2019. https://doi.org/10.1200/ JCO.2010.33.5091 (Epub 2011 Apr 18 PMID: 21502544)

13. Venook AP, Niedzwiecki D, Lenz HJ, Innocenti F, Fruth B, Meyerhardt JA, Schrag D, Greene C, O’Neil BH, Atkins JN, Berry S, Polite BN, O'Reilly EM, Goldberg RM, Hochster HS, Schilsky RL, Bertagnolli MM, El-Khoueiry AB, Watson P, Benson AB 3rd, Mulkerin DL, Mayer RJ, Blanke C (2017) Effect of firstline chemotherapy combined with cetuximab or bevacizumab on overall survival in patients with KRAS wild-type advanced or metastatic colorectal cancer: a randomized clinical trial. JAMA 317(23):2392-2401. https://doi.org/10.1001/jama.2017.7105. PMID:28632865;PMCID:PMC5545896

14. Topalian SL, Drake CG, Pardoll DM (2015) Immune checkpoint blockade: a common denominator approach to cancer therapy. Cancer Cell 13;27(4):450-61. https://doi.org/10.1016/j.ccell. 2015.03.001. Epub 2015 Apr 6. PMID: 25858804; PMCID: PMC4400238.

15. Cohen R, Rousseau B, Vidal J, Colle R, Diaz LA Jr, André T (2020) Immune checkpoint inhibition in colorectal cancer: microsatellite instability and beyond. Target Oncol 15(1):11-24. https:// doi.org/10.1007/s11523-019-00690-0 (PMID: 31786718)

16. Le DT, Durham JN, Smith KN, Wang H, Bartlett BR, Aulakh LK, Lu S, Kemberling H, Wilt C, Luber BS, Wong F, Azad NS, Rucki AA, Laheru D, Donehower R, Zaheer A, Fisher GA, Crocenzi TS, Lee JJ, Greten TF, Duffy AG, Ciombor KK, Eyring AD, Lam BH, Joe A, Kang SP, Holdhoff M, Danilova L, Cope L, Meyer C, Zhou S, Goldberg RM, Armstrong DK, Bever KM, Fader AN, Taube J, Housseau F, Spetzler D, Xiao N, Pardoll DM, Papadopoulos N, Kinzler KW, Eshleman JR, Vogelstein B, Anders RA, Diaz LA $\mathrm{Jr}$ (2017) Mismatch repair deficiency predicts response of solid tumors to PD-1 blockade. Science 28;357(6349):409-413. https:// doi.org/10.1126/science.aan6733. Epub 2017 Jun 8. PMID: 28596308; PMCID: PMC5576142

17. Overman MJ, McDermott R, Leach JL, Lonardi S, Lenz HJ, Morse MA, Desai J, Hill A, Axelson M, Moss RA, Goldberg MV, Cao ZA, Ledeine JM, Maglinte GA, Kopetz S, André T (2017) Nivolumab in patients with metastatic DNA mismatch repair-deficient or microsatellite instability-high colorectal cancer (CheckMate 142): an open-label, multicentre, phase 2 study. Lancet Oncol18(9):1182-1191. https://doi.org/10.1016/S14702045(17)30422-9. Epub 2017 Jul 19. Erratum in: Lancet Oncol 18(9):e510. PMID: 28734759; PMCID: PMC6207072

18. Chen C, Zhang F, Zhou N, Gu YM, Zhang YT, He YD, Wang L, Yang LX, Zhao Y, Li YM (2019) Efficacy and safety of immune checkpoint inhibitors in advanced gastric or gastroesophageal junction cancer: a systematic review and meta-analysis. Oncoimmunology 8(5):e1581547. https://doi.org/10.1080/2162402X. 2019.1581547.PMID:31069144;PMCID:PMC6492970
19. Benson AB 3rd, Venook AP, Cederquist L, Chan E, Chen YJ, Cooper HS, Deming D, Engstrom PF, Enzinger PC, Fichera A, Grem JL, Grothey A, Hochster HS, Hoffe S, Hunt S, Kamel A, Kirilcuk N, Krishnamurthi S, Messersmith WA, Mulcahy MF, Murphy JD, Nurkin S, Saltz L, Sharma S, Shibata D, Skibber JM, Sofocleous CT, Stoffel EM, Stotsky-Himelfarb E, Willett CG, Wu CS, Gregory KM, Freedman-Cass D (2017) Colon Cancer, Version 1. 2017, NCCN Clinical Practice Guidelines in Oncology. J Natl Compr Canc Netw 15(3):370-398. https://doi.org/10.6004/ jnccn.2017.0036. PMID: 28275037

20. Eng C, Kim TW, Bendell J, Argilés G, Tebbutt NC, Di Bartolomeo M, Falcone A, Fakih M, Kozloff M, Segal NH, Sobrero A, Yan Y, Chang I, Uyei A, Roberts L, Ciardiello F (2019) IMblaze370 Investigators. Atezolizumab with or without cobimetinib versus regorafenib in previously treated metastatic colorectal cancer (IMblaze370): a multicentre, open-label, phase 3, randomised, controlled trial. Lancet Oncol 20(6):849-861. https://doi.org/10. 1016/S1470-2045(19)30027-0. Epub 2019 Apr 16. Erratum in: Lancet Oncol 20(6):e293. PMID: 31003911

21. Chen EX, Jonker DJ, Loree JM, Kennecke HF, Berry SR, Couture F, Ahmad CE, Goffin JR, Kavan P, Harb M, Colwell B, Samimi S, Samson B, Abbas T, Aucoin N, Aubin F, Koski SL, Wei AC, Magoski NM, Tu D, O'Callaghan CJ (2020) Effect of combined immune checkpoint inhibition vs best supportive care alone in patients with advanced colorectal cancer: the Canadian Cancer Trials Group CO.26 Study. JAMA Oncol 6(6):831-838. https://doi.org/10.1001/jamaoncol.2020.0910. PMID: 32379280; PMCID: PMC7206536

22. André T, Shiu KK, Kim TW, Jensen BV, Jensen LH, Punt C, Smith D, Garcia-Carbonero R, Benavides M, Gibbs P, de la Fouchardiere C, Rivera F, Elez E, Bendell J, Le DT, Yoshino T, Van Cutsem E, Yang P, Farooqui MZH, Marinello P, Diaz LA Jr (2020) KEYNOTE-177 Investigators. Pembrolizumab in microsatellite-instability-high advanced colorectal cancer. N Engl J Med 383(23):2207-2218. https://doi.org/10.1056/NEJMoa2017699. PMID: 33264544

23. Le DT, Uram JN, Wang H, Bartlett BR, Kemberling H, Eyring AD, Skora AD, Luber BS, Azad NS, Laheru D, Biedrzycki B, Donehower RC, Zaheer A, Fisher GA, Crocenzi TS, Lee JJ, Duffy SM, Goldberg RM, de la Chapelle A, Koshiji M, Bhaijee F, Huebner T, Hruban RH, Wood LD, Cuka N, Pardoll DM, Papadopoulos N, Kinzler KW, Zhou S, Cornish TC, Taube JM, Anders RA, Eshleman JR, Vogelstein B, Diaz LA Jr (2015) PD-1 Blockade in tumors with mismatch-repair deficiency. N Engl J Med 372(26):2509-20. https://doi.org/10.1056/NEJMoa1500596. Epub 2015 May 30. PMID: 26028255; PMCID: PMC4481136

Publisher's Note Springer Nature remains neutral with regard to jurisdictional claims in published maps and institutional affiliations. 